\title{
Extracellular Vesicles and Immune System in Ageing and Immune Diseases
}

\author{
So Yeong Cheon ${ }^{1}$ and Jong Eun Lee ${ }^{2,3 *}$ \\ ${ }^{1}$ Department of Biotechnology, College of Biomedical \& Health Science, Konkuk University, Chungju 27478, ${ }^{2}$ Department of \\ Anatomy, Yonsei University College of Medicine, Seoul 03722, ${ }^{3}$ BK21 PLUS Project for Medical Science, and Brain Research \\ Institute, Yonsei University College of Medicine, Seoul 03722, Korea
}

\begin{abstract}
Immune system is essential for host homeostasis. Immune cells communicate with each other by binding to receptors or by releasing vesicles including chemokines and cytokines. Under healthy circumstances, immune cell-derived factors are critical for cellular growth, division and function, whereas under conditions such as ageing and inflammatory states, they can aggravate pathologies and cause disease. Cell-derived membranous extracellular vesicles mediate cell-to-cell communication and are implicated in various physiological and pathological processes involving ageing and age-related diseases. Extracellular vesicles are responsible for spreading detrimental factors to the surroundings and the propagation phase of inflammatory diseases. The regulation of extracellular vesicles is a putative target for treatment of inflammatory diseases. Moreover, their features are ideal for developing biomarkers and drug delivery systems modulated by bioengineering in inflammatory diseases. The present review summarizes the current understanding of extracellular vesicles in ageing and inflammatory diseases.
\end{abstract}

Key words: Ageing, Extracellular vesicles, Inflammatory disease, Biomarkers, Drug delivery system

\section{INTRODUCTION}

The conserved immune defense system is essential for host homeostasis $[1,2]$ as it triggers innate and adaptive immunity. Both mechanisms protect the host against foreign invaders [3]. The triggered innate immune system can immediately recognize nonspecific pathogens without immunological memory and rapidly lead to an inflammatory reaction [4]. Innate immune cells are recruited towards the infected and inflammatory areas to engulf foreign substances [5]. Macrophages, monocytes, neutrophils, dendritic cells and natural killer (NK) cells sense pathogen-associated molecular patterns (PAMPs) and damaged or dying cell-derived danger-associated molecular patterns (DAMPs) by their pat-

Submitted December 7, 2020, Revised January 6, 2021,

Accepted January 17,2021

* To whom correspondence should be addressed.

TEL: 82-2-2228-1646, FAX: 82-2-365-0700

e-mail: jelee@yuhs.ac tern recognition receptors (PRRs) such as cytoplasmic retinoic acid-induced gene (RIG)-I-like receptors (RLRs), absent in melanoma 2 (AIM2)-like receptors (ALRs), and nucleotide-binding oligomerization domain (NOD)-like receptors (NLRs), as well as membrane-bound Toll-like receptors (TLRs) and C-type lectin receptors (CLRs) $[3,6,7]$. Depending on the type of PRRs binding, activated immune cells initiate various intracellular signaling cascades to produce cytokines, chemokines, immune receptors and cell adhesion molecules, which are involved in the further recruitment of immune cells $[4,8]$. Innate immunity is responsible for the induction of adaptive immunity [3]. The adaptive immune system is more specific and finely tuned to fight against non-selfand self-antigens [9]. The adaptive immune system is a delayed response, which generates immunological memory after an initial encounter with specific pathogens [8]. Primary contact with a specific antigen contributes to the transformation of immune cells such as naïve $\mathrm{T}$ and $\mathrm{B}$ cells into activated states. When the same pathogen re-enters organisms, memory $\mathrm{T}$ and $\mathrm{B}$ cells promptly respond depending on their memory $[2,10]$. These cells imple-
Copyright ( Experimental Neurobiology 2021. www.enjournal.org
This is an Open Access article distributed under the terms of the Creative Commons Attribution Non-Commercial License (http://creativecommons.org/licenses/by-nc/4.0) which permits unrestricted non-commercial use, distribution, and reproduction in any medium, provided the original work is properly cited. 
ment antibody-mediated (humoral) or cell-mediated immune responses. B lymphocytes play an important role in producing immunoglobulin (Ig) antibodies that attach to and neutralize specific foreign pathogenic antigens. T lymphocytes such as cytotoxic $\mathrm{T}$ cells and helper $\mathrm{T}$ cells, are involved in cell-mediated immune responses [4]. With ageing, immune system shows chronic, sterile, and low-grade inflammation (inflammaging) and immunodeficiency (immunosenescence), and aberrant immune responses can lead to immune disorders and age-related diseases [11, 12].

Cell-derived membranous extracellular vesicles (EVs) mediate intercellular communication after their release into the extracellular environment $[13,14]$. EVs can be classified as exosome, microvesicle, and apoptotic bodies depending on their intracellular origin, size (diameter 100 to $1,000 \mathrm{~nm}$ ) or composition $[13,14]$. EVs enclosed in phospholipid bilayer contain lipids, nucleic acids and proteins (e.g., cytokines, proteinases, adhesion molecules, signal transduction proteins and chemokines) that deliver signals to the cytosol of recipient cells and activate intracellular signaling pathway by their internalization or receptor-counter receptor interactions at plasma membrane [13-15]. EVs play important roles in the regulation of physiological and pathological processes including Alzheimer disease (AD), Parkinson disease (PD) and amyotrophic lateral sclerosis (ALS) [16]. In particular, EVs are involved in regulating the immune response, inflammation and tissue homeostasis [15]. In addition, acute insults may provoke pro-inflammatory EVs serving host defense. Under chronic inflammatory conditions, such as cellular senescence, EVs delivering immunosuppressive contents act in an attempt to prevent persistent inflammatory response, acting as a counterweight to inflammatory conditions $[17,18]$. In response to the inducer, EVs evoke either pro-inflammatory or anti-inflammatory responses [19]. This review summarizes current knowledge about EVs in immune systems under ageing and inflammatory states and their potential for clinical applications.

\section{OVERVIEW OF EXTRACELLULAR VESICLES}

Exosomes (30 100 nm in diameter) are released by the endocytic pathway in various cell types and transport cell-type specific molecules [20, 21]. Late endosomes called multivesicular bodies (MVBs) or multivesicular endosomes (MVEs) containing internal intraluminal vesicles (ILVs) fuse with host plasma membrane to secrete ILVs into the extracellular environment (exosomes) [20, 21]. Otherwise, some late endosomes fuse with lysosomes to degrade cytoplasmic contents (Fig. 1) [22].

Multiple intracellular steps are required to accomplish exosome biogenesis and release. Exosome biogenesis proceeds in endosom- al sorting complexes required for transport (ESCRT) dependent or ESCRT independent manner. Sub-complexes of ESCRT comprise ESCRT-0 (Vps27, Hse1), ESCRT-I (TSG101, Vps28, Vps37, and Mvb23), ESCRT-II (Vps22, Vps25, and Vps36) and ESCRT-III (Vps20, SNF7, Vps24, Vps2, Vps60, and Vps46) [23, 24]. ESCRT-0 senses and recruits ubiquitinated cargo on endosomal membranes, and ESCRT-0 recruits ESCRT-1, which subsequently recruits ESCRT-II. Both ESCRT-I and -II are involved in membrane deformation and inward bud formation. Furthermore, ESCRT-1 recruits ESCRT-III via ESCRT-II, and ESCRT-III is implicated in scission to form ILVs $[23,25]$. Without ESCRT complexes, tetraspanins (CD9, CD81, and CD63) and ceramide are associated with exosome biogenesis [26]. Tetraspanins organize membrane microdomains, called tetraspanin-enriched microdomains (TEM), with lipids and transmembrane proteins that include Ig-superfamily (IgSF) receptors and integrins. Tetraspanins are implicated in cargo sorting into ILVs [27]. The ESCRT complex and tetraspanins play roles in protein sorting into vesicles [28].

Exosomes contain enriched cholesterol, sphingolipids (SLs) and phosphatidylcholine (PC). Ceramide (Cer), a central unit of SLs, is product of sphingomyelin (SM) hydrolysis by neutral sphingomyelinase (nSMase); it promotes membrane budding, generates ILVs [29], and is involved in lipid sorting [29, 30]. Other sphingolipid metabolite, sphingosine 1-phosphate (S1P) is also associated with cargo sorting into ILVs by binding to S1P receptors on MVBs [31]. In particular, heterogeneous nuclear ribonucleoprotein A2B1 (hnRNPA2B1) and Y-box protein 1 (YBX1) are involved in exosomal microRNA (miRNA) sorting [32,33]. Major vault protein (MVP) participates in RNA and miRNA sorting into vesicles [34, 35].

MVBs then move toward the plasma membrane for secretion via microtubule and actin cytoskeleton [36], and the motor proteins (kinesins, dynein, and myosins) superfamilies are responsible for vesicular transport [37]. The Rab family of small guanosine-5'triphosphates (GTPases) regulate intracellular vesicle trafficking and membrane fusion [early endosome (Rab4 and Rab5), recycling endosome (Rab11), late endosome (Rab7 and Rab9), and exosome secretion (Rab27)] [28, 38]. Rab27a and Rab27b are associated with MVB docking at the plasma membrane [39]. Soluble N-ethylmaleimide-sensitive factor attachment protein receptors (SNAREs) might contribute to the docking process by assembling vesicular SNAREs (v-SNAREs) and target SNAREs ( $\mathrm{t}$ SNAREs). These trans-SNARE complexes are implicated in MVB fusion with the plasma membrane. Therefore, SNARE proteins are required for exosome release into the extracellular environment $[40,41]$. Exosome secretion is also mediated by activation of the transcriptional factor, p53 [42]. 


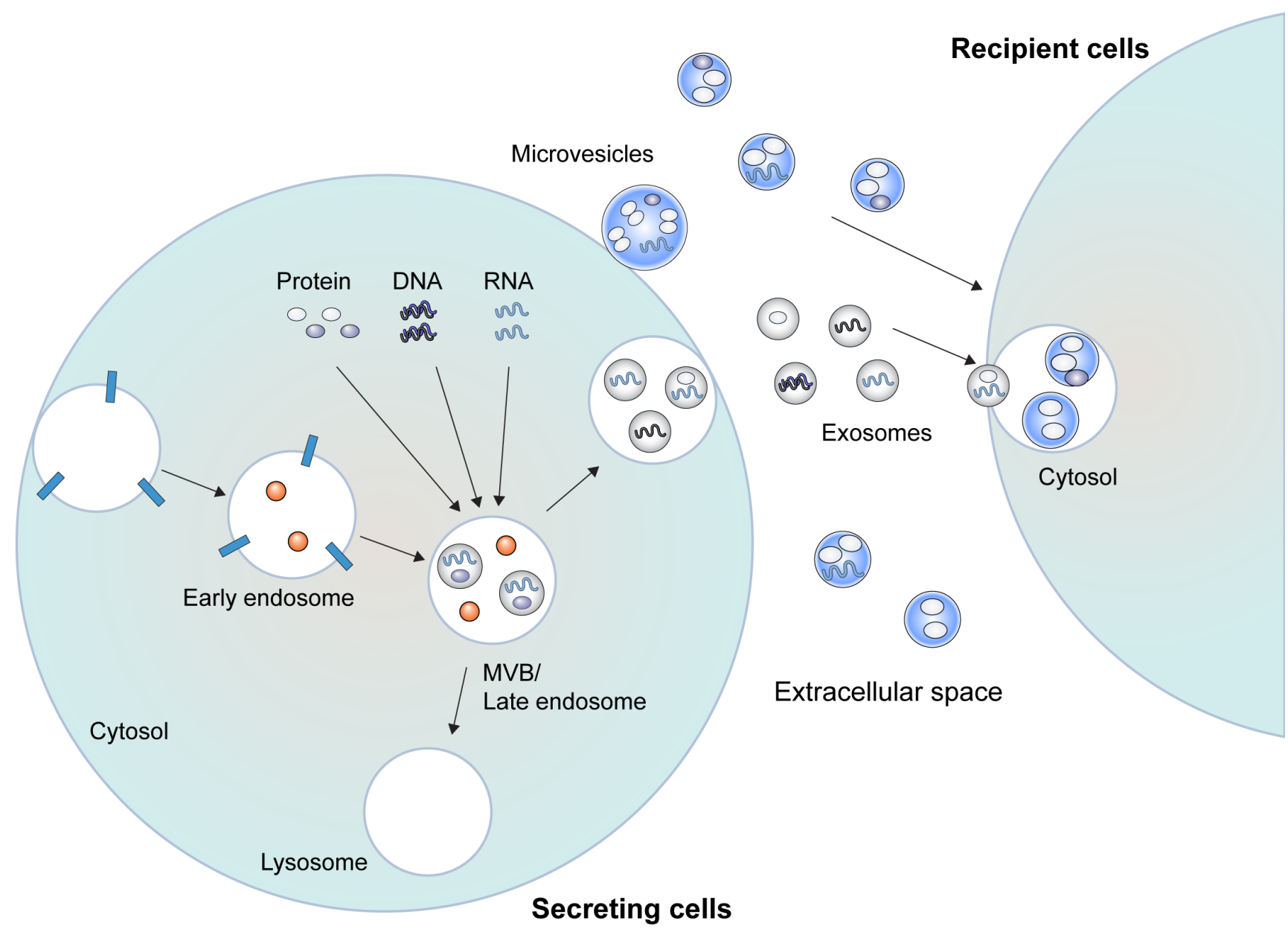

Fig. 1. Schematic overview of the extracellular vesicles (EVs). EVs enclosed in phospholipid bilayer from secreting cells contain nucleic acids and proteins that deliver signals to the cytosol of recipient cells. EVs can be classified as exosome, microvesicle, and apoptotic bodies depending on their intracellular origin, composition and size.

Microvesicles are directly derived from the cell surface via outward bud formation and fission, and range from 50 1,000 nm in diameter [13]. Plasma membrane redistribution and contraction of the cytoskeletal structure contribute to microvesicle formation [43]. When cargo components move to the cellular periphery at sites of microvesicle shedding, changes in membrane-bending associated proteins and the plasma lipid composition change, and become involved in membrane rigidity and curvature, causing membrane budding [44]. Lipid raft microdomains are enriched in sphingolipids and cholesterol, and are important in the budding process $[43,45]$. Acid SMase (aSMase) generates cone-shaped Cer, which alters microvesicle membrane curvature and fluidity [46, 47]. Cholesterol might be involved in microvesicle shedding [48, 49]. Modification of membrane asymmetry is ATP-dependently generated by aminophospholipid translocases such as flippases and floppases that move phospholipids from outer to inner leaflets and vice versa, respectively. Scramblases that are ATP-independent and $\mathrm{Ca}^{+}$-dependent, are involved in the distribution of the plasma membrane, by non-specifically translocating phospholipids between outer and inner leaflets [50]. Phosphatidylserine (PS) is translocated to the outer leaflet for shedding and lipid rafts also play pivotal roles in PS exposure [51].

Membrane bending and budding processes are also regulated by contractile proteins that add contractile or tensile forces $[43,44]$. Actin-myosin interaction induces fission to release microvesicles from the surface of parent cells. The small GTP-binding protein ADP-ribosylation factor 6 (ARF6) facilitates the phospholipase D (PLD)-extracellular signal-regulated kinase (ERK)- myosin light chain kinase (MLCK) signaling pathway, which activates myosin light chain (MLC) that subsequently promotes actomyosin contractility at the necks of forming vesicles, thus releasing microvesicles into the extracellular space [52].

Apoptotic bodies are vesicles that bleb from the plasma membranes of cells undergoing apoptosis [53]. Apoptotic cells can 
generate diverse apoptotic cell-derived EVs (ApoEVs) including membrane-bound vesicles (ApoBDs) and apoptotic microvesicles (ApoMVs) [54]. Apoptotic bodies allow phagocytes including macrophages and DCs to recognize and engulf apoptotic cells [53]. They can transport fragmented DNA and cytoplasmic organelles, as well as cytokines and miRNA; therefore, they play crucial roles in immune regulation during infection and autoimmunity [54, $55]$.

\section{IMMUNE CELLS AND EXTRACELLULAR VESICLES IN IMMUNE SYSTEM}

All types of immune cells such as macrophages, neutrophils, dendritic cells (DCs), T, and B lymphocytes secrete EVs, which are essential for cell-cell communication [56-60]. After recognition of foreign agents or stimuli, they release EVs with altered cargo [61]. Recent evidence indicates cytokines are encapsulated in EVs and then released into extracellular environment $[19,62]$. These EVs include the cytokines [interleukin (IL)-1 ra, IL-1 $\beta$, IL-6, IL8 , and IL-10], chemokines [monocyte chemoattractant protein-1 (MCP-1) and regulated upon activation, normal T cell expressed and secreted (RANTES)], miRNA, and foreign constituents, which are important for the innate and adaptive immune systems [19, 63, 64]. Also, EVs provoke either pro-inflammatory or anti-inflammatory responses depending on the stimuli [19].

Macrophages are derived from the yolk sac, fetal livers or bone marrow and participate in phagocytosis, tissue remodeling, and homeostasis. They have the important ability to scan surrounding signals via their sensors such as TLRs, NLRs, CLRs, RLRs and ALRs $[56,65]$. Activated macrophages release cytokines [IL-1 $\beta$, IL6, IL-12, IL-18, and IL-10], growth factors [transforming growth factor (TGF)- $\beta$ ] and chemokines [chemokine C-X-C motif ligand (CXCL)1, CXCL2, and CXCL10] [65, 66]. Macrophages-derived EVs regulate the phenotype and function of recipient cells and are implicated in infections, such as those caused by Mycobacterium tuberculosis and human immunodeficiency retrovirus (HIV). These EVs can also deliver mycobacterial or viral components [64].

Neutrophils are specific polymorphonuclear leukocyte (PMNs) that are involved in acute and chronic inflammation. Neutrophils are abundant in the circulation [67]. During inflammation due to host-derived and bacterial-derived stimulants, circulating neutrophils are captured by endothelial adhesion molecules and recruited neutrophils form neutrophil extracellular traps (NETs) $[67,68]$. In particular, neutrophils store granules containing microbicidal or enzymatic substances that are secreted upon activation. Azurophilic granules carry myeloperoxidase (MPO), serine proteases including neutrophil elastase (NE) and cathepsin G (CG) [57,
68]. Neutrophils also produce the cytokines and chemokines, IL$1 \alpha$, IL-1 $\beta$, IL-12, tumor necrosis factor (TNF)- $\alpha$, IL-8, granulocyte colony-stimulating factor (G-CSF), interferon- $\alpha$, and interferon- $\beta$ [57]. Neutrophil-derived EVs can modify the inflammatory response of target immune cells by modulating production of proor anti- inflammatory cytokines [69]. In addition, EVs from neutrophils exhibit protective effects against inflammatory arthritis by inducing anti-inflammatory responses [70].

DCs are antigen-presenting cells (APCs) that are important for the induction of innate immunity as well as involved in adaptive immunity [71]. DCs are implicated in regulation of NK and NK T cells. Also, DCs interact with T and B cells: These cells prime naïve $\mathrm{T}$ cells (especially $\mathrm{CD} 4^{+} \mathrm{T}$ helper (Th) cells), which are required for T cell-dependent activation of B cells activation [71]. Also, DCs can induce naïve and memory $B$ cell activation and support differentiation activated naïve B cells to plasma cells [71]. Classical DCs (cDCs) have CD11b, CD11c, and CD13 on their surfaces and express TLR2, TLR4, TLR10, and NLR. Cytokines secreted by cDCs include IL-8, IL-10, IL-12, and TNF- $\alpha$ [58]. Plasmacytoid dendritic cells (pDCs) produce type 1 interferon (IFN) against foreign pathogens [72]. Plasmacytoid DCs express surface markers such as CD303 and CD45RA, sensors such as TLR7 and TLR9, and release IFN- $\alpha$, IL-6, and TNF [58]. Microparticles from patients with systemic lupus erythematosus (SLE) induce the production of proinflammatory cytokines, such as TNF, IFN- $\alpha$, and IFN- $\gamma$, by pDCs [73].

T lymphocytes originate from bone marrow, mature in the thymus for selection, then migrate to the periphery. Naïve T lymphocytes can continuously circulate between blood and secondary lymphoid organs such as spleen and lymph nodes though the lymphatic system, and proliferate and differentiate into various types of $\mathrm{T}$ lymphocytes such as effector and memory cells after encountering antigens or costimulatory molecules of DCs [74,75]. The major types of T lymphocytes are CD4 expressing Th cells and CD8 expressing cytotoxic $\mathrm{T}(\mathrm{Tc})$ cells. The $\mathrm{CD}^{+} \mathrm{T}$ cells comprise T regulatory (Treg), T follicular helper (Tfh), Th1, Th2, Th9, Th17, and Th22 types. These cells produce the anti-inflammatory or pro-inflammatory cytokines: IFN- $\gamma$ and TNF (Th1), IL-4 and IL-5 (Th2), IL-9 (Th9), IL-17, IL-21, and IL-22 (Th17), IL-22 (Th22), IL-10 and TGF- $\beta$ (Treg), and IL-21 (Tfh) [59]. T helper cells support B cell maturation for the generation of antibodies and regulate cytotoxic $\mathrm{T}$ cell activation [59, 76]. Regulatory T cells are important for maintaining self-tolerance $[75]$ and $\mathrm{CD} 8^{+} \mathrm{T}$ cells generate IFN- $\gamma$, TNF, and IL-2, and kill cells infected with viruses [77]. Upon T cell receptor (TCR) activation, T cells release EVs [78]. Furthermore, overactivated T cell-derived EVs contain Fas ligand (FasL) and Apo2 ligand (Apo2L), which are associated with the 
activation of cell death pathway [79].

Like T lymphocytes, B lymphocytes originate form bone marrow and express B cell receptors (BCR) that allows them to initiate activation after contact with antigens [80]. During T cell-dependent activation, $\mathrm{B}$ cells can become activated and differentiate into plasma and memory B cells with the help of T cells [80]. T cell-independent $\mathrm{B}$ cell activation results in production of $\mathrm{B}$ cell forming low-affinity antibodies in response to lipopolysaccharides (LPS) and glycolipids [81]. B lymphocytes are implicated in the productions of antibodies and cytokines. In particular, B regulatory (Breg) cells can release IL-10, which is responsible for supporting the differentiation of Treg cells, and the inhibition of Th1, Th17, and $\mathrm{CD}^{+} \mathrm{T}$ cells [60]. Moreover, B cell-derived EVs containing MHC class II complexes are secreted in response to the interaction with antigen-specific $\mathrm{T}$ cells and BCR crosslinking, which plays an important role in the immune response [82].

\section{SENESCENCE-ASSOCIATED SECRETORY PHENOTYPE AND EXTRACELLULAR VESICLES IN AGEING}

Cellular senescence is characterized as a stress response to extracellular or intracellular insults. This senescence system can induce a permanent state of cell-cycle arrest and prevent malignant transformation [83]. Senescent cells undergo phenotypic changes such as acquiring the senescence-associated secretory phenotype (SASP). The SASP consists of cytokines [IL-1, IL-6, and IL-8], chemokines [CXCL-1, 2, chemokine C-C motif ligand (CCL)-3, 8, 11, 13 , and 20], proteases [matrix metalloproteinase (MMP)-1, MMP3 , and MMP-10], and growth factors [insulin-like growth factor (IGF) and granulocyte-macrophage colony-stimulating factor (GM-CSF)] [12, 83]. Senescent cells are normally cleared by immune cells [84]. However, senescent cells accumulate in multiple tissues due to age-related immunosenescence [12]. Concomitantly, SASP contributes to inflammaging, promoting inflammation by spreading the senescence phenotype to surrounding cells, which can lead to tissue dysfunction and age-related disease progression $[11,12]$.

For instance, aged vascular smooth muscle cells express IL6, CCL2, ICAM-1, and TLR4 compared to young [85]. Plasma TNF- $\alpha$ and IL- 8 are increased in elderly humans [86]. The gene expression of IFN, IL-2, IL-1A, MMP-13, CXCL2, CXCL9, CXCL14, and CXCL20, which are closely associated with nuclear factor (NF)-kappa B activity, is elevated in aged human fibroblasts [87]. Monocytes from elderly persons produce increased amounts of IL-6, IL1-ra, and C-reactive protein (CRP), but not TNF- $\alpha$ and IL-1 compared with younger persons [88]. Circulating EVs from the cerebrospinal fluid (CSF) of aged rats have higher levels of
CD63 level but not IL-1 $\beta$ level compared with young adult rats [89]. Notably, aged populations are vulnerable to pathological conditions [90-92]. Systemic inflammation induced by injected LPS results in upregulated IL-1 $\beta$ and IL-10 levels in the brain and plasma of aged mice compared with adult mice. Notably, LPS induces aged microglia-derived IL-1 $\beta$, IL-10, and TLR2 [90]. Microarray analyses showed increased levels of complement component (C) 1q, C3, C4, MHC class I and II, CD68, CD44, and CD83 in brains from aged mice compared with adult mice. Similarly, LPS induced higher IL-6 and IL-1 $\beta$ levels in aged, than adult mice [91], and IL-6 production is upregulated in aged splenocytes with or without LPS stimulation [92].

Senescent cells are generally metabolically active and enhance EV secretion [93]. Ageing can influence the concentration, size, and functions of circulating EVs throughout the body [94]. Also, miRNAs such as miR-21 and miR-223 are increased within the exosomes [18]. The senescence-associated increase in EVs might be mediated partially by $\mathrm{p} 53[42,95]$. Transcription factor $\mathrm{p} 53$ can modulate the cell-cycle, DNA repair, cellular senescence and ageing [96], and targets endosomal compartment genes such as tumor suppressor-activated pathway 6 (TSAP6) and charged multivesicular body protein 4C (CHMP4C), which are implicated in exosome production. Under stress, p53 activation contributes to changes in membrane and vesicle trafficking [97]. The membrane phospholipid composition also changes with age [98]. The activation of nSMase in the liver and of nSMase and ceramidase in the brain and kidney during ageing is prominent, suggesting increased ceramide and/or sphingosine production [99]. Brains from aged monkeys show age-dependent endocytic pathology, as Rab GTPases including Rab5, Rab7 and Rab11 are increased [100]. Taken together, senescent cells exhibit enhanced or suppressed immune activities with ageing, and have altered EVs biogenesis and secretion.

In addition, senescent cells inducing inflammation state can further increase the cancer incidence in the aged individuals [21]. Cancer cells can exploit EVs for EV-induced immunosuppressive environment in tumor tissues or areas, which prevents the recognition by immune cells and removal of cancer cells [18]. Also, EVs from stem/progenitor cells have crucial ability to repair damaged tissues and modulate ageing process [101].

\section{EXTRACELLULAR VESICLES IN HUMAN DISEASES}

Under inflammatory conditions such as autoimmune and infectious diseases, EVs can carry PAMPs, DAMPs, autoantigens, and cytokines that contribute to the pathogenesis of human diseases by suppressing or enhancing immune responses [102]. In acute 
injuries, immune cells are likely to secrete pro-inflammatory EVs. In chronic or inflammatory diseases, they seem to release pro- or anti- inflammatory EVs depending on the inducers [18]. Thus, EVs might be key mediators in inflammatory diseases.

\section{Inflammatory bowel disease}

Inflammatory bowel disease (IBD) is an autoimmune condition that is due to the failure of immune tolerance to self-antigens. It leads to the production of auto-antibodies and impaired host tissues or organs. Patients with IBD are vulnerable to developing diverse autoimmune diseases such as psoriasis, coeliac disease, and multiple sclerosis [103]. Symptoms of IBD are abdominal pain, diarrhoea, and fever [104], and it is characterized by a dysregulated immune system and a chronic inflammatory response to an abnormal enteric microbiota, and genetic/environmental factors in the gastrointestinal (GI) tract. The major types of IBD are Crohn's disease and ulcerative colitis (UC). Crohn's disease involves the ileum, colon, and entire intestine, and UC involves the rectum and colon $[105,106]$. A link between IBD and EVs has been identified. Intestinal luminal EVs from patients with IBD contain high levels of TNF- $\alpha$, IL- 6 and IL- 8 [107], and Th1 and Th17 cells are involved in the pathogenesis of IBD [108, 109]. Th1 cell-derived IFN- $\gamma$ and Th17 cell-derived IL-17 are key players in lesions of Crohn's disease, as IL-12 and IL-23 production by DC is elevated [108]. Biopsies of intestinal tissues from patients with Crohn's disease and UC have shown that Th17 cells and Th17-related cytokines, such as IL-17 and IL-21, are upregulated [110]. Furthermore, the colon and ileum of patients with IBD express IL-8 and high levels of Th17 effector cytokines including IL-17A and IL-22 [111]. Many cytokines derived from immune cells are associated with IBD, indicating the importance of regulating these cytokines [112]. EVs derived from DC with a TGF- $\beta 1$ modification inhibit Th17 and delay IBD [113].

\section{Rheumatoid arthritis}

RA is a chronic autoimmune disease that is characterized by the production of autoantibodies, persistent synovitis, and joint damage $[114,115]$. Autoantibodies such as rheumatoid factors (RFs) and anti-citrullinated protein antibodies (ACPAs) are associated with the severe clinical symptoms of RA such as pain, stiffness, swelling, and joint damage [114]. Rheumatoid factors are IgG, IgM and $\operatorname{IgA}$ that sense epitopes in the Fc fragment of $\operatorname{IgG}$ [116], and ACPAs recognize citrullinated peptides/proteins [117]. Both RFs and ACPAs are predominantly expressed in synovial fluid and blood of patients with RA [118]. The synovial compartment is a major region of inflammatory process in RA, and synovial cells, such as fibroblast-like and macrophage-like synoviocytes, are in- volved in cytokine overproduction, as well as cartilage and bone destruction in joints [115]. Elevated numbers of EVs in joints and EVs in patients are likely to play key roles in pathogenesis of RA $[119,120]$. Excessive cytokines and chemokines within synovial tissues are responsible for endothelial cell activation, and the infiltration and accumulation of immune cells including leukocyte and $\mathrm{CD} 4^{+} \mathrm{T}$ cells, thus worsening the inflammatory response [114, $121,122]$. Both TNF- $\alpha$ and IL-1 might induce leukocyte recruitment to inflamed areas $[123,124]$. Infiltrated $\mathrm{CD}^{+} \mathrm{T}$ cells generate IL- 2 and IFN- $\gamma$. T cells interact with DCs that express MHC class II or cytokines such as IFN- $\gamma$, TNF- $\alpha$, and IL-17, and activate macrophages and monocytes [122]. Direct interaction between $\mathrm{T}$ cells and macrophage contributes to TNF- $\alpha$ production [125]. IL-17 can also trigger macrophages to produce TNF- $\alpha$ and IL- $1 \beta$ [126]. Conversely, monocytes/macrophages are sources of TNF- $\alpha$, IL-6, and IL-12 [127, 128], and regulators of T cell differentiation; for example, IL-12 and IFN- $\gamma$ regulate Th1, and IL- $1 \beta$ and IL- 6 regulate Th17 cell differentiation $[129,130]$. These Th1 and Th17 cells are pathogenic and abundant in joints of patients with RA $[131,132]$. EVs from DCs expressing IL-10 are immunosuppressive effects [133] and those from DCs expressing the tryptophan catabolic enzyme, indoleamine 2,3-dioxygenase (IDO) inhibit T cell activation and activate Treg cells, thus manifesting immunosuppressive and anti-inflammatory effects [134].

\section{Systemic lupus erythematosus}

SLE is a heterogeneous and systemic autoimmune disease caused by genetic susceptibility, aberrant immune disturbance, and hormonal as well as environmental risk factors $[135,136]$. The symptoms of SLE are rash, nephritis, serositis, and thrombocytopenia, and SLE is characterized by the production of autoantibodies, disrupted self-tolerance, and organ dysfunction [137, 138]. Usually, SLE influences the kidneys, skin, blood, and joints [135, 137]. Patients with lupus nephritis have shown high levels of autoantibodies including anti-double-stranded DNA (dsDNA) antibodies [139]. SLE is associated with single-nucleotide polymorphisms (SNPs) in immune-associated genes or T-cell function-associated genes $[137,138]$. Furthermore, TLRs, IL-10, IL-17A and costimulatory molecule CTLA-4 (CD152) polymorphisms are associated with SLE susceptibility [140-142]. EVs in patients with SLE express higher levels of IL-6, TNF- $\alpha$, IL- $1 \beta$, and IFN- $\alpha$, than healthy individuals [143]. Microparticles from SLE plasma contain elevated levels of cytokines including IL-6, TNF, and IFN- $\alpha$, and costimulatory surface proteins including CD80, CD86, and CD40. In addition, patients with SLE have higher proportions of apoptotic microparticles compared with heathy persons [73]. Microparticles from patients express high levels of Ig and complement proteins, 
and low levels of cytoskeletal and organelle composition proteins [144]. T cells in SLE help B cells to produce high-affinity IgG autoantibodies through TCR and MHC binding and costimulatory interactions such as CD28-B7 and CD40-CD40 ligand, and activated $\mathrm{T}$ cells are involved in cytokine production [137]. Anti-dsDNA antibodies can penetrate cells, subsequently leading to DNA fragmentation and apoptosis. Also, such antibody internalization is responsible for the upregulation of inflammatory cytokines such as TNF- $\alpha$, IL-6, and IL-1 $\beta$ [145].

\section{Type 1 diabetes}

Type 1 diabetes (T1D) is a metabolic disease that is characterized by hyperglyceamia and inadequate insulin production. It results from a loss of insulin-producing pancreatic $\beta$ cells in the islets of Langerhans. Patients with T1D are dependent on exogenous insulin replacement, and are at risk of developing serious complications including neuropathy, retinopathy, and nephropathy [146]. Most patients develop immunological disturbances including autoantibodies or viral infections [147]. The pancreas of patients with T1D contains large populations of cytotoxic $\mathrm{CD} 8^{+} \mathrm{T}$ cells within islets, increased $\mathrm{CD} 68^{+}$macrophages, $\mathrm{CD} 20^{+} \mathrm{B}$, and $\mathrm{CD} 4^{+}$ T cells, and low levels of Forkhead box protein P3 (FOXP3) ${ }^{+}$Treg cells and NK cells are evident during insulitis [148]. Pancreatic tissues from T1D donors also contain islets with infiltrative $\mathrm{CD} 8^{+} \mathrm{T}$ cells, human leukocyte antigen (HLA) class I hyperexpression, and $\beta$ cell destruction in insulitic lesions [149]. The secretion of IL-17 by $\mathrm{CD}^{+} \mathrm{T}$ cells in response to $\beta$ cell autoantigens is involved in $\beta$ cell death in D1M [150]. EVs released in human and rat pancreatic islets carry autoantigens such as insulin/proinsulin, GAD65, and IA-2, which are associated with a loss of self-tolerance and the development of T1D [151]. In diabetic mice, EVs from islet mesenchymal stem cell-like cells promote the production of IFN- $\gamma$ and the activation of autoreactive $\mathrm{T}$ and $\mathrm{B}$ cells [152].

\section{Human immunodeficiency virus infection}

Individuals infected with the HIV are at risk of developing acquired immunodeficiency syndrome (AIDS). Antiretroviral therapy (ART) can suppress HIV replication by inhibiting the reverse transcription of viral RNA and prolong life. Nevertheless, HIV in patients treated with ART is often accompanied by nonAIDS comorbidities such as cardiovascular disease, neurological disease, and cancers [153]. Infection with HIV is characterized by persistent inflammation and immune dysfunction [154], and massive amounts of inflammatory mediators, such as cytokines and chemokines [155]. Infection with HIV also promotes the secretion of EVs from T cells, monocytes, macrophages, and dendritic cells [156]. Plasma from patient infected with HIV has EVs containing
IL-1 $\alpha$, IL-2, IL-12p70, TNF- $\alpha$, CXCL10, and CCL2 [157]. Infected patients have reduced numbers of $\mathrm{CD} 4^{+}$cells [153]. The HIV targets $\mathrm{CD} 4^{+} \mathrm{T}$ cells and coreceptors such as CCR 5 and CXCR4 to penetrate cells [158], and $\mathrm{CD} 4^{+} \mathrm{T}$ cells expressing CCR5 gradually become depleted in the GI tract, a major site of $\mathrm{CD} 4^{+} \mathrm{T}$ cell, via destruction of lymph node [154]. EVs are involved in both the pathogenesis of, and antiviral responses against HIV [156]. HIV exploits intracellular vesicle trafficking for its egress. The ESCRT system (TSG101) is needed for HIV release by being recruited at sites of viral budding [159]. The most prevalent protein in HIV, Nef is implicated in the vesicular trafficking network by interacting with Rab11, elevated microvesicle exocytosis, and apoptosis in $\mathrm{CD} 4^{+} \mathrm{T}$ cells. Nef from HIV is secreted from infected cells via CD $45^{+}$microvesicles in plasma [160]. In contrast, EVs stimulate the immune system to inhibit HIV spreading. EVs from infected cells contain APOBEC3G, which edits the HIV genome and targets HIV virion infectivity protein (vif), thus conferring antiretroviral capacity on recipient cells [161]. IFN- $\alpha$ is thought to restrict HIV replication and infection of $\mathrm{CD} 4{ }^{+} \mathrm{T}$ cells by eliciting the APOBEG3 family in dendritic cells [162]. Besides this, tripartite-motif-containing $5 a$ (TRIM5 $\alpha$ ) and tetherin are factors that restrict HIV [163].

\section{Mycobacterium tuberculosis infection}

Tuberculosis is a contagious disease with a steadily declining global incidence, but drug resistance is increasing. Tuberculosis is caused by infection with the pathogenic bacterium, Mycobacterium tuberculosis, that usually invades hosts by inhalation into the alveoli, where causes the formation of granuloma and subsequent necrosis [164]. Alveolar macrophages, DCs and monocytederived macrophages are involved in the phagocytic process of M. tuberculosis [165], which inhibits phagosome maturation into phagolysosomes in infected macrophages [166]. The glycosylated protein of M. tuberculosis can impede DC-mediated Th1 and Th17 polarization and block the protective effects of the bacillus Calmette-Guérin (BCG) vaccine [167]. M. tuberculosis is involved in changes in the membrane composition of EVs, such as vimentin and heat shock protein (HSP) 90, via infected macrophages [168]. In addition, M. tuberculosis infection results in stimulation of $\mathrm{CD}^{+}$and $\mathrm{CD} 8^{+}$that express antigen-specific IL-2 and IFN- $\gamma$, which enhance the protective immune response of the host [169].

\section{CLINICAL APPLICATIONS OF EXTRACELLULAR VESICLES}

EVs mediate intercellular communication and are implicated in various physiological and pathological processes. For that reason, EVs are likely to play crucial roles in inflammatory diseases and ageing. Even though EVs involve cellular homeostasis, they con- 


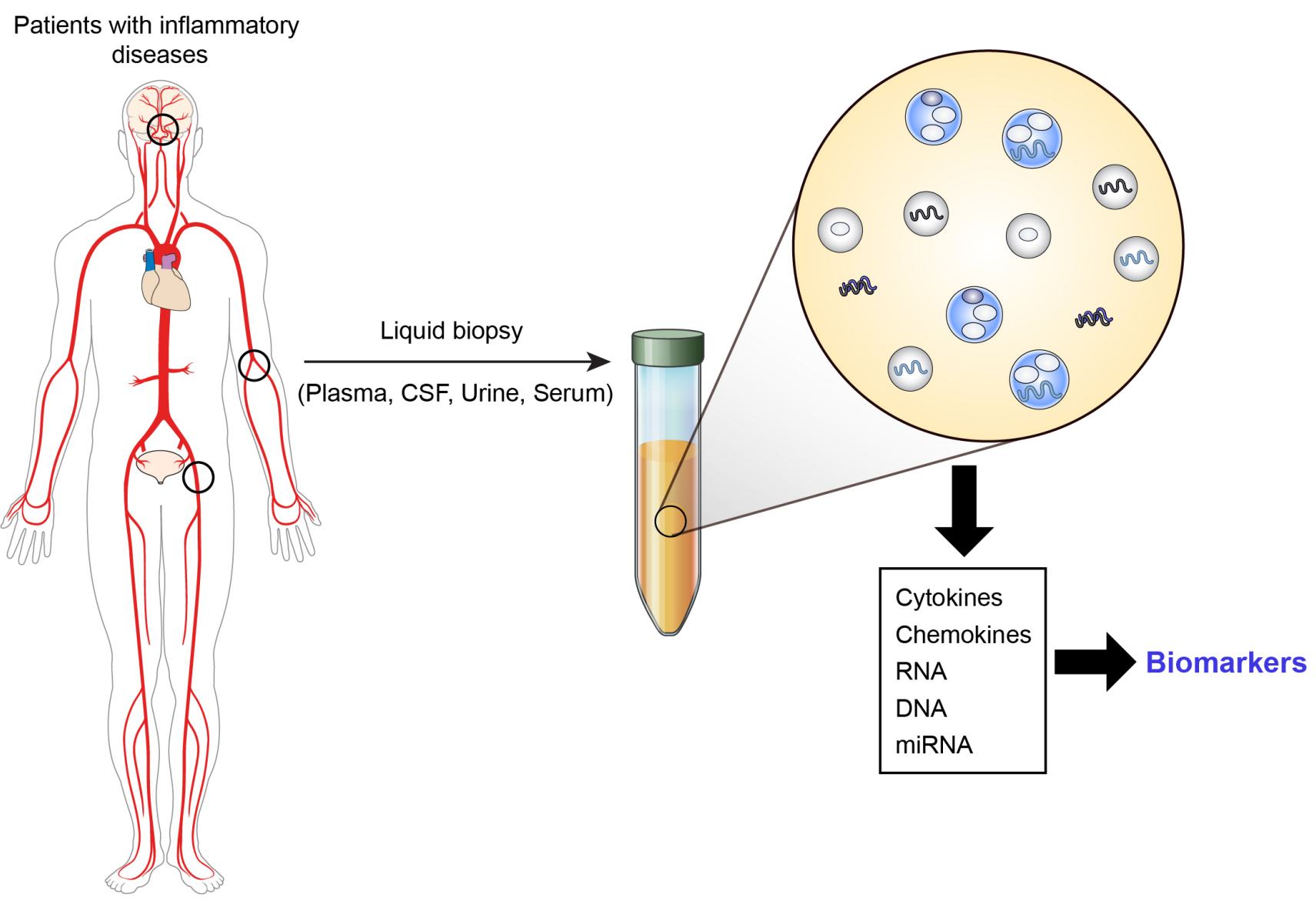

Fig. 2. Extracellular vesicles (EVs) as potential biomarkers in immune system disorders. EVs could serve as biomarkers in inflammatory diseases. Disease stage can be monitored by analyzing circulating EVs in body fluids including plasma, CSF, urine, and serum.

tribute to the ageing or pathological environment of hosts, and propagate the disease by carrying host or pathogen-derived elements [170, 171]. EVs transport and transfer pro- or anti-inflammatory cytokines, chemokines, and other inflammatory mediators from infected or resident immune cells to recipient cells, indicating their immunomodulatory capacity [19]. Thus, EVs have promising potential as biomarkers [172]. Cellular senescence is responsible for changes in circulating EVs dependently upon ageing [94]. The characteristic of SASP and potential of EVs as ageing biomarkers have been suggested through the results of proteomic analysis and profiling [172]. Increasing evidence indicates that EVs could serve as biomarkers in human diseases including cancer, central nervous system (CNS), and inflammatory diseases [173-175]. Disease stage can be monitored by analyzing circulating EVs in body fluids [173]. Microvesicles and exosomes in the CSF of injured CNS system contain specific biomarkers [174]. Myeloid-derived EVs and their cytokine expression in the CSF of patients with autoimmune disease can reflect disease progression and are considered as disease markers [175]. Thus, accumulated evidence indicates that EVs could be useful biomarkers for diagnostic, prognostic, predictive, and therapeutic interventions (Fig. 2).

EVs might be ideal for drug delivery from the viewpoint of pharmaceutical drug development and useful in bioengineering [176, 177]. Therapeutic substances loaded into EVs can be transferred to target cells regardless of distance $[178,179]$. Thanks to their selfderived nature, customized EVs have low immunogenicity and toxicity, and do not invoke immune responses [178]. The nature and size of EVs mean that they can protect their cargo against phagocytic clearance [177]. Lipid bilayer EVs are very stable and enough to be maintained in the circulation $[178,180]$. Moreover, EVs can penetrate the blood-brain barrier to the CNS [179, 181]. The key features of EVs are desirable for delivering therapeutic agents to combat targeted pathological factors and for designing clinical applications. 


\section{EXTRACELLULAR VESICLES IN NEURODEGENERATIVE DISEASES}

In the CNS, EVs are secreted by multiple cells, including microglia, astrocyte, and neuron, and contribute to intercellular communication [16]. EVs are implicated in neurodegenerative diseases such as AD, PD, and Huntington disease (HD) [16]. EVs carry misfolded or aggregated proteins and, therefore, could be used as biomarkers [16]. In $\mathrm{AD}$, amyloid $\beta(\mathrm{A} \beta)$ peptide is secreted via $\mathrm{EVs}$, and brain tissues from AD patients show EV proteins accumulated in amyloid plaques [182]. EVs secreted by neuronal cells can bind soluble $A \beta$, and the CSF-derived EVs from AD patients lead to mitochondrial impairment and neuronal cell apoptosis [183, 184]. Furthermore, EVs containing extracellular a-synuclein were observed in the CSF of patients with PD, which correlated with the degree of cognitive impairment [185]. Mutant $\alpha$-synuclein plays a major role in PD pathology [186]. Also, mutant huntingtin transported by EVs propagates the HD phenotype, thus influencing motor and cognitive dysfunctions and striatal neuronal cell loss in HD [187]. EVs from stem cells or engineered EVs exhibit neuroprotective properties, including the release of neurotrophic factors and the ability to reduce neuroregeneration [188]. These characteristics suggest that EVs could be used for treating neurodegenerative diseases as well as immune diseases [188].

\section{CONCLUSION}

Extracellular vesicles are important for cellular homeostasis and cell-cell communication by carrying membrane and cargo components. They transport cytokines, chemokines, autoantigens, and danger signals that play potential roles in processes ranging from initiation to the progression of human diseases. EVs are involved in the ageing process and spreading pathological or disease states, thus, their regulation might prevent or retard the ageing process and be novel targets for therapeutic intervention. EVs are also promising tools for clinical applications such as biomarkers and EV-based immunotherapy in immune diseases.

\section{ACKNOWLEDGEMENTS}

This work was supported by the National Research Foundation of Korea (NRF) grant funded by the Korea government (MSIT) (NRF-2020R1C1C1010613) to So Yeong Cheon, and the Korea government (MSIT) (NRF- 2017R1A2B2005350) to Jong Eun Lee. The authors thank MID (Medical Illustration \& Design), a part of the Medical Research Support Services of Yonsei University College of Medicine, for all artistic support related to this work.

\section{CONFLICT OF INTEREST}

The authors declare no conflict of interest. The funders had no role in the design of the study, in the writing of the manuscript, or in the decision to publish this article.

\section{REFERENCES}

1. Kotas ME, Medzhitov R (2015) Homeostasis, inflammation, and disease susceptibility. Cell 160:816-827.

2. Chaplin DD (2010) Overview of the immune response. J Allergy Clin Immunol 125(2 Suppl 2):S3-S23.

3. Iwasaki A, Medzhitov R (2015) Control of adaptive immunity by the innate immune system. Nat Immunol 16:343-353.

4. Marshall JS, Warrington R, Watson W, Kim HL (2018) An introduction to immunology and immunopathology. Allergy Asthma Clin Immunol 14(Suppl 2):49.

5. Germic N, Frangez Z, Yousefi S, Simon HU (2019) Regulation of the innate immune system by autophagy: monocytes, macrophages, dendritic cells and antigen presentation. Cell Death Differ 26:715-727.

6. Takeuchi O, Akira S (2010) Pattern recognition receptors and inflammation. Cell 140:805-820.

7. Gong T, Liu L, Jiang W, Zhou R (2020) DAMP-sensing receptors in sterile inflammation and inflammatory diseases. Nat Rev Immunol 20:95-112.

8. Mogensen TH (2009) Pathogen recognition and inflammatory signaling in innate immune defenses. Clin Microbiol Rev 22:240-273, Table of Contents.

9. Bonilla FA, Oettgen HC (2010) Adaptive immunity. J Allergy Clin Immunol 125(2 Suppl 2):S33-S40.

10. Cronkite DA, Strutt TM (2018) The regulation of inflammation by innate and adaptive lymphocytes. J Immunol Res 2018:1467538.

11. Thomas R, Wang W, Su DM (2020) Contributions of agerelated thymic involution to immunosenescence and inflammaging. Immun Ageing 17:2.

12. van Deursen JM (2014) The role of senescent cells in ageing. Nature 509:439-446.

13. van Niel G, D’Angelo G, Raposo G (2018) Shedding light on the cell biology of extracellular vesicles. Nat Rev Mol Cell Biol 19:213-228.

14. Tkach M, Théry C (2016) Communication by extracellular vesicles: where we are and where we need to go. Cell 164:1226-1232.

15. Robbins PD, Morelli AE (2014) Regulation of immune responses by extracellular vesicles. Nat Rev Immunol 14:195- 
208.

16. Thompson AG, Gray E, Heman-Ackah SM, Mäger I, Talbot K, Andaloussi SE, Wood MJ, Turner MR (2016) Extracellular vesicles in neurodegenerative disease - pathogenesis to biomarkers. Nat Rev Neurol 12:346-357.

17. Couch Y, Akbar N, Davis S, Fischer R, Dickens AM, Neuhaus AA, Burgess AI, Rothwell PM, Buchan AM (2017) Inflammatory stroke extracellular vesicles induce macrophage activation. Stroke 48:2292-2296.

18. Salminen A, Kaarniranta K, Kauppinen A (2020) Exosomal vesicles enhance immunosuppression in chronic inflammation: impact in cellular senescence and the aging process. Cell Signal 75:109771.

19. Aiello A, Giannessi F, Percario ZA, Affabris E (2020) An emerging interplay between extracellular vesicles and cytokines. Cytokine Growth Factor Rev 51:49-60.

20. Théry C, Zitvogel L, Amigorena S (2002) Exosomes: composition, biogenesis and function. Nat Rev Immunol 2:569-579.

21. Takasugi M (2018) Emerging roles of extracellular vesicles in cellular senescence and aging. Aging Cell 17:e12734.

22. Cheon SY, Kim H, Rubinsztein DC, Lee JE (2019) Autophagy, cellular aging and age-related human diseases. Exp Neurobiol 28:643-657.

23. Colombo M, Moita C, van Niel G, Kowal J, Vigneron J, Benaroch P, Manel N, Moita LF, Théry C, Raposo G (2013) Analysis of ESCRT functions in exosome biogenesis, composition and secretion highlights the heterogeneity of extracellular vesicles. J Cell Sci 126(Pt 24):5553-5565.

24. Hurley JH, Hanson PI (2010) Membrane budding and scission by the ESCRT machinery: it's all in the neck. Nat Rev Mol Cell Biol 11:556-566.

25. Wollert T, Hurley JH (2010) Molecular mechanism of multivesicular body biogenesis by ESCRT complexes. Nature 464:864-869.

26. Simons M, Raposo G (2009) Exosomes--vesicular carriers for intercellular communication. Curr Opin Cell Biol 21:575581.

27. Perez-Hernandez D, Gutiérrez-Vázquez C, Jorge I, LópezMartín S, Ursa A, Sánchez-Madrid F, Vázquez J, Yáñez-Mó M (2013) The intracellular interactome of tetraspanin-enriched microdomains reveals their function as sorting machineries toward exosomes. J Biol Chem 288:11649-11661.

28. Villarroya-Beltri C, Baixauli F, Gutiérrez-Vázquez C, SánchezMadrid F, Mittelbrunn M (2014) Sorting it out: regulation of exosome loading. Semin Cancer Biol 28:3-13.

29. Trajkovic K, Hsu C, Chiantia S, Rajendran L, Wenzel D, Wieland F, Schwille P, Brügger B, Simons M (2008) Ceramide triggers budding of exosome vesicles into multivesicular endosomes. Science 319:1244-1247.

30. Boulgaropoulos B, Rappolt M, Sartori B, Amenitsch H, Pabst G (2012) Lipid sorting by ceramide and the consequences for membrane proteins. Biophys J 102:2031-2038.

31. Kajimoto T, Okada T, Miya S, Zhang L, Nakamura S (2013) Ongoing activation of sphingosine 1-phosphate receptors mediates maturation of exosomal multivesicular endosomes. Nat Commun 4:2712.

32. Villarroya-Beltri C, Gutiérrez-Vázquez C, Sánchez-Cabo F, Pérez-Hernández D, Vázquez J, Martin-Cofreces N, MartinezHerrera DJ, Pascual-Montano A, Mittelbrunn M, SánchezMadrid F (2013) Sumoylated hnRNPA2B1 controls the sorting of miRNAs into exosomes through binding to specific motifs. Nat Commun 4:2980.

33. Shurtleff MJ, Temoche-Diaz MM, Karfilis KV, Ri S, Schekman $\mathrm{R}$ (2016) Y-box protein 1 is required to sort microRNAs into exosomes in cells and in a cell-free reaction. Elife 5:e19276.

34. Statello L, Maugeri M, Garre E, Nawaz M, Wahlgren J, Papadimitriou A, Lundqvist C, Lindfors L, Collén A, Sunnerhagen P, Ragusa M, Purrello M, Di Pietro C, Tigue N, Valadi H (2018) Identification of RNA-binding proteins in exosomes capable of interacting with different types of RNA: RBP-facilitated transport of RNAs into exosomes. PLoS One 13:e0195969.

35. Teng Y, Ren Y, Hu X, Mu J, Samykutty A, Zhuang X, Deng Z, Kumar A, Zhang L, Merchant ML, Yan J, Miller DM, Zhang HG (2017) MVP-mediated exosomal sorting of miR-193a promotes colon cancer progression. Nat Commun 8:14448.

36. Hessvik NP, Llorente A (2018) Current knowledge on exosome biogenesis and release. Cell Mol Life Sci 75:193-208.

37. Kamal A, Goldstein LS (2000) Connecting vesicle transport to the cytoskeleton. Curr Opin Cell Biol 12:503-508.

38. Stenmark H, Olkkonen VM (2001) The Rab GTPase family. Genome Biol 2:REVIEWS3007.

39. Ostrowski M, Carmo NB, Krumeich S, Fanget I, Raposo G, Savina A, Moita CF, Schauer K, Hume AN, Freitas RP, Goud B, Benaroch P, Hacohen N, Fukuda M, Desnos C, Seabra MC, Darchen F, Amigorena S, Moita LF, Thery C (2010) Rab27a and Rab27b control different steps of the exosome secretion pathway. Nat Cell Biol 12:19-30; sup pp 1-13.

40. Fader CM, Sánchez DG, Mestre MB, Colombo MI (2009) TI-VAMP/VAMP7 and VAMP3/cellubrevin: two v-SNARE proteins involved in specific steps of the autophagy/multivesicular body pathways. Biochim Biophys Acta 1793:19011916.

41. Bonifacino JS, Glick BS (2004) The mechanisms of vesicle budding and fusion. Cell 116:153-166. 
42. Lespagnol A, Duflaut D, Beekman C, Blanc L, Fiucci G, Marine JC, Vidal M, Amson R, Telerman A (2008) Exosome secretion, including the DNA damage-induced p53-dependent secretory pathway, is severely compromised in TSAP6/ Steap3-null mice. Cell Death Differ 15:1723-1733.

43. Muralidharan-Chari V, Clancy JW, Sedgwick A, D’SouzaSchorey C (2010) Microvesicles: mediators of extracellular communication during cancer progression. J Cell Sci 123(Pt 10):1603-1611.

44. Tricarico C, Clancy J, D’Souza-Schorey C (2017) Biology and biogenesis of shed microvesicles. Small GTPases 8:220-232.

45. Munro S (2003) Lipid rafts: elusive or illusive? Cell 115:377388.

46. Mencarelli C, Martinez-Martinez P (2013) Ceramide function in the brain: when a slight tilt is enough. Cell Mol Life Sci 70:181-203.

47. Verderio C, Gabrielli M, Giussani P (2018) Role of sphingolipids in the biogenesis and biological activity of extracellular vesicles. J Lipid Res 59:1325-1340.

48. Pfrieger FW, Vitale N (2018) Cholesterol and the journey of extracellular vesicles. J Lipid Res 59:2255-2261.

49. Del Conde I, Shrimpton CN, Thiagarajan P, López JA (2005) Tissue-factor-bearing microvesicles arise from lipid rafts and fuse with activated platelets to initiate coagulation. Blood 106:1604-1611.

50. Hankins HM, Baldridge RD, Xu P, Graham TR (2015) Role of flippases, scramblases and transfer proteins in phosphatidylserine subcellular distribution. Traffic 16:35-47.

51. Wei H, Malcor JM, Harper MT (2018) Lipid rafts are essential for release of phosphatidylserine-exposing extracellular vesicles from platelets. Sci Rep 8:9987.

52. Muralidharan-Chari V, Clancy J, Plou C, Romao M, Chavrier P, Raposo G, D’Souza-Schorey C (2009) ARF6-regulated shedding of tumor cell-derived plasma membrane microvesicles. Curr Biol 19:1875-1885.

53. Poon IK, Lucas CD, Rossi AG, Ravichandran KS (2014) Apoptotic cell clearance: basic biology and therapeutic potential. Nat Rev Immunol 14:166-180.

54. Caruso S, Poon IKH (2018) Apoptotic cell-derived extracellular vesicles: more than just debris. Front Immunol 9:1486.

55. Hauser P, Wang S, Didenko VV (2017) Apoptotic bodies: selective detection in extracellular vesicles. Methods Mol Biol 1554:193-200.

56. Okabe Y, Medzhitov R (2016) Tissue biology perspective on macrophages. Nat Immunol 17:9-17.

57. Witko-Sarsat V, Rieu P, Descamps-Latscha B, Lesavre P, Halbwachs-Mecarelli L (2000) Neutrophils: molecules, functions and pathophysiological aspects. Lab Invest 80:617-653.

58. Schlitzer A, Zhang W, Song M, Ma X (2018) Recent advances in understanding dendritic cell development, classification, and phenotype. F1000Res 7:F1000 Faculty Rev-1558.

59. Golubovskaya V, Wu L (2016) Different subsets of T cells, memory, effector functions, and CAR-T immunotherapy. Cancers (Basel) 8:36.

60. Mauri C, Bosma A (2012) Immune regulatory function of B cells. Annu Rev Immunol 30:221-241.

61. Chan BD, Wong WY, Lee MM, Cho WC, Yee BK, Kwan YW, Tai WC (2019) Exosomes in inflammation and inflammatory disease. Proteomics 19:e1800149.

62. Barnes BJ, Somerville CC (2020) Modulating cytokine production via select packaging and secretion from extracellular vesicles. Front Immunol 11:1040.

63. Fitzgerald W, Freeman ML, Lederman MM, Vasilieva E, Romero R, Margolis L (2018) A system of cytokines encapsulated in extracellular vesicles. Sci Rep 8:8973.

64. Wang Y, Zhao M, Liu S, Guo J, Lu Y, Cheng J, Liu J (2020) Macrophage-derived extracellular vesicles: diverse mediators of pathology and therapeutics in multiple diseases. Cell Death Dis 11:924.

65. Lee JW, Nam H, Yu SW (2016) Systematic analysis of translocator protein $18 \mathrm{kDa}$ (TSPO) ligands on toll-like receptorsmediated pro-inflammatory responses in microglia and astrocytes. Exp Neurobiol 25:262-268.

66. Arango Duque G, Descoteaux A (2014) Macrophage cytokines: involvement in immunity and infectious diseases. Front Immunol 5:491.

67. Kolaczkowska E, Kubes P (2013) Neutrophil recruitment and function in health and inflammation. Nat Rev Immunol 13:159-175.

68. Amulic B, Cazalet C, Hayes GL, Metzler KD, Zychlinsky A (2012) Neutrophil function: from mechanisms to disease. Annu Rev Immunol 30:459-489.

69. Pliyev BK, Kalintseva MV, Abdulaeva SV, Yarygin KN, Savchenko VG (2014) Neutrophil microparticles modulate cytokine production by natural killer cells. Cytokine 65:126129.

70. Headland SE, Jones HR, Norling LV, Kim A, Souza PR, Corsiero E, Gil CD, Nerviani A, Dell'Accio F, Pitzalis C, Oliani SM, Jan LY, Perretti M (2015) Neutrophil-derived microvesicles enter cartilage and protect the joint in inflammatory arthritis. Sci Transl Med 7:315ra190.

71. Banchereau J, Briere F, Caux C, Davoust J, Lebecque S, Liu YJ, Pulendran B, Palucka K (2000) Immunobiology of dendritic cells. Annu Rev Immunol 18:767-811. 
72. Worbs T, Hammerschmidt SI, Förster R (2017) Dendritic cell migration in health and disease. Nat Rev Immunol 17:30-48.

73. Dieker J, Tel J, Pieterse E, Thielen A, Rother N, Bakker M, Fransen J, Dijkman HB, Berden JH, de Vries JM, Hilbrands LB, van der Vlag J (2016) Circulating apoptotic microparticles in systemic lupus erythematosus patients drive the activation of dendritic cell subsets and prime neutrophils for NETosis. Arthritis Rheumatol 68:462-472.

74. Kumar BV, Connors TJ, Farber DL (2018) Human T cell development, localization, and function throughout life. Immunity 48:202-213.

75. van den Broek T, Borghans JAM, van Wijk F (2018) The full spectrum of human naive T cells. Nat Rev Immunol 18:363373.

76. Weinstein JS, Hernandez SG, Craft J (2012) T cells that promote B-cell maturation in systemic autoimmunity. Immunol Rev 247:160-171.

77. Schmidt ME, Varga SM (2020) Cytokines and CD8 T cell immunity during respiratory syncytial virus infection. Cytokine 133:154481.

78. Blanchard N, Lankar D, Faure F, Regnault A, Dumont C, Raposo G, Hivroz C (2002) TCR activation of human T cells induces the production of exosomes bearing the TCR/CD3/ zeta complex. J Immunol 168:3235-3241.

79. Martínez-Lorenzo MJ, Anel A, Gamen S, Monle I, Lasierra P, Larrad L, Piñeiro A, Alava MA, Naval J (1999) Activated human T cells release bioactive Fas ligand and APO2 ligand in microvesicles. J Immunol 163:1274-1281.

80. Cyster JG, Allen CDC (2019) B cell responses: cell interaction dynamics and decisions. Cell 177:524-540.

81. Tsai DY, Hung KH, Chang CW, Lin KI (2019) Regulatory mechanisms of $\mathrm{B}$ cell responses and the implication in B cellrelated diseases. J Biomed Sci 26:64.

82. Muntasell A, Berger AC, Roche PA (2007) T cell-induced secretion of MHC class II-peptide complexes on B cell exosomes. EMBO J 26:4263-4272.

83. Coppé JP, Desprez PY, Krtolica A, Campisi J (2010) The senescence-associated secretory phenotype: the dark side of tumor suppression. Annu Rev Pathol 5:99-118.

84. Prata LGPL, Ovsyannikova IG, Tchkonia T, Kirkland JL (2018) Senescent cell clearance by the immune system: emerging therapeutic opportunities. Semin Immunol 40:101275.

85. Song Y, Shen H, Schenten D, Shan P, Lee PJ, Goldstein DR (2012) Aging enhances the basal production of IL-6 and CCL2 in vascular smooth muscle cells. Arterioscler Thromb Vasc Biol 32:103-109.
86. Ong SM, Hadadi E, Dang TM, Yeap WH, Tan CT, Ng TP, Larbi A, Wong SC (2018) The pro-inflammatory phenotype of the human non-classical monocyte subset is attributed to senescence. Cell Death Dis 9:266.

87. Kriete A, Mayo KL, Yalamanchili N, Beggs W, Bender P, Kari C, Rodeck U (2008) Cell autonomous expression of inflammatory genes in biologically aged fibroblasts associated with elevated NF-kappaB activity. Immun Ageing 5:5.

88. Roubenoff R, Harris TB, Abad LW, Wilson PW, Dallal GE, Dinarello CA (1998) Monocyte cytokine production in an elderly population: effect of age and inflammation. J Gerontol A Biol Sci Med Sci 53:M20-M26.

89. Gomes de Andrade G, Reck Cechinel L, Bertoldi K, Galvão F, Valdeci Worm P, Rodrigues Siqueira I (2018) The aging process alters IL-1 $\beta$ and CD63 levels differently in extracellular vesicles obtained from the plasma and cerebrospinal fluid. Neuroimmunomodulation 25:18-22.

90. Henry CJ, Huang Y, Wynne AM, Godbout JP (2009) Peripheral lipopolysaccharide (LPS) challenge promotes microglial hyperactivity in aged mice that is associated with exaggerated induction of both pro-inflammatory IL-1beta and antiinflammatory IL-10 cytokines. Brain Behav Immun 23:309317.

91. Godbout JP, Chen J, Abraham J, Richwine AF, Berg BM, Kelley KW, Johnson RW (2005) Exaggerated neuroinflammation and sickness behavior in aged mice following activation of the peripheral innate immune system. FASEB J 19:1329-1331.

92. Park J, Miyakawa T, Shiokawa A, Nakajima-Adachi H, Tanokura M, Hachimura S (2014) Splenic stromal cells from aged mice produce higher levels of IL-6 compared to young mice. Mediators Inflamm 2014:826987.

93. Urbanelli L, Buratta S, Sagini K, Tancini B, Emiliani C (2016) Extracellular vesicles as new players in cellular senescence. Int J Mol Sci 17:1408.

94. Alibhai FJ, Lim F, Yeganeh A, DiStefano PV, Binesh-Marvasti T, Belfiore A, Wlodarek L, Gustafson D, Millar S, Li SH, Weisel RD, Fish JE, Li RK (2020) Cellular senescence contributes to age-dependent changes in circulating extracellular vesicle cargo and function. Aging Cell 19:e13103.

95. Yu X, Harris SL, Levine AJ (2006) The regulation of exosome secretion: a novel function of the p53 protein. Cancer Res 66:4795-4801.

96. Rufini A, Tucci P, Celardo I, Melino G (2013) Senescence and aging: the critical roles of p53. Oncogene 32:5129-5143.

97. Yu X, Riley T, Levine AJ (2009) The regulation of the endosomal compartment by $\mathrm{p} 53$ the tumor suppressor gene. FEBS J 276:2201-2212. 
98. Laganiere S, Yu BP (1993) Modulation of membrane phospholipid fatty acid composition by age and food restriction. Gerontology 39:7-18.

99. Sacket SJ, Chung HY, Okajima F, Im DS (2009) Increase in sphingolipid catabolic enzyme activity during aging. Acta Pharmacol Sin 30:1454-1461.

100. Kimura N, Inoue M, Okabayashi S, Ono F, Negishi T (2009) Dynein dysfunction induces endocytic pathology accompanied by an increase in Rab GTPases: a potential mechanism underlying age-dependent endocytic dysfunction. J Biol Chem 284:31291-31302.

101. Robbins PD (2017) Extracellular vesicles and aging. Stem Cell Investig 4:98.

102. Buzas EI, György B, Nagy G, Falus A, Gay S (2014) Emerging role of extracellular vesicles in inflammatory diseases. Nat Rev Rheumatol 10:356-364.

103. Wilson JC, Furlano RI, Jick SS, Meier CR (2016) Inflammatory bowel disease and the risk of autoimmune diseases. J Crohns Colitis 10:186-193.

104. GBD 2017 Inflammatory Bowel Disease Collaborators (2020) The global, regional, and national burden of inflammatory bowel disease in 195 countries and territories, 1990-2017: a systematic analysis for the Global Burden of Disease Study 2017. Lancet Gastroenterol Hepatol 5:17-30.

105. Abraham C, Cho JH (2009) Inflammatory bowel disease. $\mathrm{N}$ Engl J Med 361:2066-2078.

106. Lee SH, Kwon JE, Cho ML (2018) Immunological pathogenesis of inflammatory bowel disease. Intest Res 16:26-42.

107. Mitsuhashi S, Feldbrügge L, Csizmadia E, Mitsuhashi M, Robson SC, Moss AC (2016) Luminal extracellular vesicles (EVs) in inflammatory bowel disease (IBD) exhibit proinflammatory effects on epithelial cells and macrophages. Inflamm Bowel Dis 22:1587-1595.

108. Feng T, Qin H, Wang L, Benveniste EN, Elson CO, Cong Y (2011) Th17 cells induce colitis and promote Th1 cell responses through IL-17 induction of innate IL-12 and IL-23 production. J Immunol 186:6313-6318.

109. Lee SY, Lee SH, Yang EJ, Kim EK, Kim JK, Shin DY, Cho ML (2015) Metformin ameliorates inflammatory bowel disease by suppression of the STAT3 signaling pathway and regulation of the between Th17/Treg balance. PLoS One 10:e0135858.

110. Jiang W, Su J, Zhang X, Cheng X, Zhou J, Shi R, Zhang H (2014) Elevated levels of Th17 cells and Th17-related cytokines are associated with disease activity in patients with inflammatory bowel disease. Inflamm Res 63:943-950.

111. Bogaert S, Laukens D, Peeters H, Melis L, Olievier K, Boon N,
Verbruggen G, Vandesompele J, Elewaut D, De Vos M (2010) Differential mucosal expression of Th17-related genes between the inflamed colon and ileum of patients with inflammatory bowel disease. BMC Immunol 11:61.

112. Moschen AR, Tilg H, Raine T (2019) IL-12, IL-23 and IL-17 in IBD: immunobiology and therapeutic targeting. Nat Rev Gastroenterol Hepatol 16:185-196.

113. Cai Z, Zhang W, Yang F, Yu L, Yu Z, Pan J, Wang L, Cao X, Wang J (2012) Immunosuppressive exosomes from TGF- $\beta 1$ genemodified dendritic cells attenuate Th17-mediated inflammatory autoimmune disease by inducing regulatory $\mathrm{T}$ cells. Cell Res 22:607-610.

114. Smolen JS, Aletaha D, McInnes IB (2016) Rheumatoid arthritis. Lancet 388:2023-2038.

115. Scott DL, Wolfe F, Huizinga TW (2010) Rheumatoid arthritis. Lancet 376:1094-1108.

116. Wines BD, Gavin A, Powell MS, Steinitz M, Buchanan RR, Mark Hogarth P (2003) Soluble FcgammaRIIa inhibits rheumatoid factor binding to immune complexes. Immunology 109:246-254.

117. Kurowska W, Kuca-Warnawin EH, Radzikowska A, Maśliński W (2017) The role of anti-citrullinated protein antibodies (ACPA) in the pathogenesis of rheumatoid arthritis. Cent Eur J Immunol 42:390-398.

118. van Delft MAM, Huizinga TWJ (2020) An overview of autoantibodies in rheumatoid arthritis. J Autoimmun 110:102392.

119. Berckmans RJ, Nieuwland R, Tak PP, Böing AN, Romijn FP, Kraan MC, Breedveld FC, Hack CE, Sturk A (2002) Cellderived microparticles in synovial fluid from inflamed arthritic joints support coagulation exclusively via a factor VIIdependent mechanism. Arthritis Rheum 46:2857-2866.

120. Cloutier N, Tan S, Boudreau LH, Cramb C, Subbaiah R, Lahey L, Albert A, Shnayder R, Gobezie R, Nigrovic PA, Farndale RW, Robinson WH, Brisson A, Lee DM, Boilard E (2013) The exposure of autoantigens by microparticles underlies the formation of potent inflammatory components: the microparticle-associated immune complexes. EMBO Mol Med 5:235-249.

121. McInnes IB, Schett G (2007) Cytokines in the pathogenesis of rheumatoid arthritis. Nat Rev Immunol 7:429-442.

122. Smolen JS, Steiner G (2003) Therapeutic strategies for rheumatoid arthritis. Nat Rev Drug Discov 2:473-488.

123. Issekutz AC, Meager A, Otterness I, Issekutz TB (1994) The role of tumour necrosis factor-alpha and IL-1 in polymorphonuclear leucocyte and $\mathrm{T}$ lymphocyte recruitment to joint inflammation in adjuvant arthritis. Clin Exp Immunol 97:2632. 
124. Pettipher ER, Higgs GA, Henderson B (1986) Interleukin 1 induces leukocyte infiltration and cartilage proteoglycan degradation in the synovial joint. Proc Natl Acad Sci U S A 83:8749-8753.

125. McInnes IB, Leung BP, Sturrock RD, Field M, Liew FY (1997) Interleukin-15 mediates $\mathrm{T}$ cell-dependent regulation of tumor necrosis factor-alpha production in rheumatoid arthritis. Nat Med 3:189-195.

126. Jovanovic DV, Di Battista JA, Martel-Pelletier J, Jolicoeur FC, He Y, Zhang M, Mineau F, Pelletier JP (1998) IL-17 stimulates the production and expression of proinflammatory cytokines, IL-beta and TNF-alpha, by human macrophages. J Immunol 160:3513-3521.

127. Sakkas LI, Johanson NA, Scanzello CR, Platsoucas CD (1998) Interleukin-12 is expressed by infiltrating macrophages and synovial lining cells in rheumatoid arthritis and osteoarthritis. Cell Immunol 188:105-110.

128. Firestein GS, Alvaro-Gracia JM, Maki R (1990) Quantitative analysis of cytokine gene expression in rheumatoid arthritis. J Immunol 144:3347-3353.

129. Zheng Y, Sun L, Jiang T, Zhang D, He D, Nie H (2014) TNFa promotes Th17 cell differentiation through IL- 6 and IL-1 $\beta$ produced by monocytes in rheumatoid arthritis. J Immunol Res 2014:385352.

130. Tau GZ, von der Weid T, Lu B, Cowan S, Kvatyuk M, Pernis A, Cattoretti G, Braunstein NS, Coffman RL, Rothman PB (2000) Interferon gamma signaling alters the function of $\mathrm{T}$ helper type 1 cells. J Exp Med 192:977-986.

131. Kotake S, Yago T, Kobashigawa T, Nanke Y (2017) The plasticity of Th17 cells in the pathogenesis of rheumatoid arthritis. J Clin Med 6:67.

132. Li S, Yin H, Zhang K, Wang T, Yang Y, Liu X, Chang X, Zhang M, Yan X, Ren Y, Pan W, Zhang L (2017) Effector T helper cell populations are elevated in the bone marrow of rheumatoid arthritis patients and correlate with disease severity. Sci Rep $7: 4776$.

133. Kim SH, Lechman ER, Bianco N, Menon R, Keravala A, Nash J, Mi Z, Watkins SC, Gambotto A, Robbins PD (2005) Exosomes derived from IL-10-treated dendritic cells can suppress inflammation and collagen-induced arthritis. J Immunol 174:6440-6448.

134. Bianco NR, Kim SH, Ruffner MA, Robbins PD (2009) Therapeutic effect of exosomes from indoleamine 2,3-dioxygenasepositive dendritic cells in collagen-induced arthritis and delayed-type hypersensitivity disease models. Arthritis Rheum 60:380-389.

135. Lisnevskaia L, Murphy G, Isenberg D (2014) Systemic lupus erythematosus. Lancet 384:1878-1888.

136. Dörner T, Furie R (2019) Novel paradigms in systemic lupus erythematosus. Lancet 393:2344-2358.

137. Rahman A, Isenberg DA (2008) Systemic lupus erythematosus. N Engl J Med 358:929-939.

138. Tsokos GC (2011) Systemic lupus erythematosus. N Engl J Med 365:2110-2121.

139. ter Borg EJ, Horst G, Hummel EJ, Limburg PC, Kallenberg CG (1990) Measurement of increases in anti-double-stranded DNA antibody levels as a predictor of disease exacerbation in systemic lupus erythematosus. A long-term, prospective study. Arthritis Rheum 33:634-643.

140. Lee YH, Lee HS, Choi SJ, Ji JD, Song GG (2012) Associations between TLR polymorphisms and systemic lupus erythematosus: a systematic review and meta-analysis. Clin Exp Rheumatol 30:262-265.

141. Liu P, Song J, Su H, Li L, Lu N, Yang R, Peng Z (2013) IL-10 gene polymorphisms and susceptibility to systemic lupus erythematosus: a meta-analysis. PLoS One 8:e69547.

142. Ahmed S, Ihara K, Kanemitsu S, Nakashima H, Otsuka T, Tsuzaka K, Takeuchi T, Hara T (2001) Association of CTLA4 but not CD28 gene polymorphisms with systemic lupus erythematosus in the Japanese population. Rheumatology (Oxford) 40:662-667.

143. Lee JY, Park JK, Lee EY, Lee EB, Song YW (2016) Circulating exosomes from patients with systemic lupus erythematosus induce an proinflammatory immune response. Arthritis Res Ther 18:264.

144. Østergaard O, Nielsen CT, Iversen LV, Tanassi JT, Knudsen S, Jacobsen S, Heegaard NH (2013) Unique protein signature of circulating microparticles in systemic lupus erythematosus. Arthritis Rheum 65:2680-2690.

145. Wang X, Xia Y (2019) Anti-double stranded DNA antibodies: origin, pathogenicity, and targeted therapies. Front Immunol 10:1667.

146. Atkinson MA, Eisenbarth GS, Michels AW (2014) Type 1 diabetes. Lancet 383:69-82.

147. DiMeglio LA, Evans-Molina C, Oram RA (2018) Type 1 diabetes. Lancet 391:2449-2462.

148. Willcox A, Richardson SJ, Bone AJ, Foulis AK, Morgan NG (2009) Analysis of islet inflammation in human type 1 diabetes. Clin Exp Immunol 155:173-181.

149. Coppieters KT, Dotta F, Amirian N, Campbell PD, Kay TW, Atkinson MA, Roep BO, von Herrath MG (2012) Demonstration of islet-autoreactive CD8 T cells in insulitic lesions from recent onset and long-term type 1 diabetes patients. J Exp Med 209:51-60. 
150. Arif S, Moore F, Marks K, Bouckenooghe T, Dayan CM, Planas R, Vives-Pi M, Powrie J, Tree T, Marchetti P, Huang GC, Gurzov EN, Pujol-Borrell R, Eizirik DL, Peakman M (2011) Peripheral and islet interleukin-17 pathway activation characterizes human autoimmune diabetes and promotes cytokinemediated $\beta$-cell death. Diabetes 60:2112-2119.

151. Cianciaruso C, Phelps EA, Pasquier M, Hamelin R, Demurtas D, Alibashe Ahmed M, Piemonti L, Hirosue S, Swartz MA, De Palma M, Hubbell JA, Baekkeskov S (2017) Primary human and rat $\beta$-cells release the intracellular autoantigens GAD65, IA-2, and proinsulin in exosomes together with cytokineinduced enhancers of immunity. Diabetes 66:460-473.

152. Rahman MJ, Regn D, Bashratyan R, Dai YD (2014) Exosomes released by islet-derived mesenchymal stem cells trigger autoimmune responses in NOD mice. Diabetes 63:1008-1020.

153. Maartens G, Celum C, Lewin SR (2014) HIV infection: epidemiology, pathogenesis, treatment, and prevention. Lancet 384:258-271.

154. Brenchley JM, Schacker TW, Ruff LE, Price DA, Taylor JH, Beilman GJ, Nguyen PL, Khoruts A, Larson M, Haase AT, Douek DC (2004) CD4 $4^{+}$T cell depletion during all stages of HIV disease occurs predominantly in the gastrointestinal tract. J Exp Med 200:749-759.

155. Paiardini M, Müller-Trutwin M (2013) HIV-associated chronic immune activation. Immunol Rev 254:78-101.

156. Chettimada S, Lorenz DR, Misra V, Dillon ST, Reeves RK, Manickam C, Morgello S, Kirk GD, Mehta SH, Gabuzda D (2018) Exosome markers associated with immune activation and oxidative stress in HIV patients on antiretroviral therapy. Sci Rep 8:7227.

157. Konadu KA, Huang MB, Roth W, Armstrong W, Powell M, Villinger F, Bond V (2016) Isolation of exosomes from the plasma of HIV-1 positive individuals. J Vis Exp (107):53495.

158. Princen K, Hatse S, Vermeire K, De Clercq E, Schols D (2004) Establishment of a novel CCR5 and CXCR4 expressing CD $4^{+}$ cell line which is highly sensitive to HIV and suitable for high-throughput evaluation of CCR5 and CXCR4 antagonists. Retrovirology 1:2.

159. Garrus JE, von Schwedler UK, Pornillos OW, Morham SG, Zavitz KH, Wang HE, Wettstein DA, Stray KM, Côté M, Rich RL, Myszka DG, Sundquist WI (2001) Tsg101 and the vacuolar protein sorting pathway are essential for HIV-1 budding. Cell 107:55-65.

160. Raymond AD, Campbell-Sims TC, Khan M, Lang M, Huang MB, Bond VC, Powell MD (2011) HIV Type 1 Nef is released from infected cells in CD $45^{+}$microvesicles and is present in the plasma of HIV-infected individuals. AIDS Res Hum Ret- roviruses 27:167-178.

161. Khatua AK, Taylor HE, Hildreth JE, Popik W (2009) Exosomes packaging APOBEC3G confer human immunodeficiency virus resistance to recipient cells. J Virol 83:512-521.

162. Mohanram V, Sköld AE, Bächle SM, Pathak SK, Spetz AL (2013) IFN- $\alpha$ induces APOBEC3G, F, and A in immature dendritic cells and limits HIV-1 spread to CD4 ${ }^{+} \mathrm{T}$ cells. J Immunol 190:3346-3353.

163. Malim MH, Bieniasz PD (2012) HIV Restriction factors and mechanisms of evasion. Cold Spring Harb Perspect Med 2:a006940.

164. Dheda K, Barry CE 3rd, Maartens G (2016) Tuberculosis. Lancet 387:1211-1226.

165. van Crevel R, Ottenhoff TH, van der Meer JW (2002) Innate immunity to Mycobacterium tuberculosis. Clin Microbiol Rev 15:294-309.

166. Fratti RA, Chua J, Vergne I, Deretic V (2003) Mycobacterium tuberculosis glycosylated phosphatidylinositol causes phagosome maturation arrest. Proc Natl Acad Sci U S A 100:54375442.

167. Satchidanandam V, Kumar N, Jumani RS, Challu V, Elangovan S, Khan NA (2014) The glycosylated Rv1860 protein of Mycobacterium tuberculosis inhibits dendritic cell mediated TH1 and TH17 polarization of T cells and abrogates protective immunity conferred by BCG. PLoS Pathog 10:e1004176.

168. Diaz G, Wolfe LM, Kruh-Garcia NA, Dobos KM (2016) Changes in the membrane-associated proteins of exosomes released from human macrophages after Mycobacterium tuberculosis infection. Sci Rep 6:37975.

169. Cheng Y, Schorey JS (2013) Exosomes carrying mycobacterial antigens can protect mice against Mycobacterium tuberculosis infection. Eur J Immunol 43:3279-3290.

170. Panagiotou N, Neytchev O, Selman C, Shiels PG (2018) Extracellular vesicles, ageing, and therapeutic interventions. Cells 7:110.

171. Robbins PD, Dorronsoro A, Booker CN (2016) Regulation of chronic inflammatory and immune processes by extracellular vesicles. J Clin Invest 126:1173-1180.

172. Basisty N, Kale A, Jeon OH, Kuehnemann C, Payne T, Rao C, Holtz A, Shah S, Sharma V, Ferrucci L, Campisi J, Schilling B (2020) A proteomic atlas of senescence-associated secretomes for aging biomarker development. PLoS Biol 18:e3000599.

173. Melo SA, Luecke LB, Kahlert C, Fernandez AF, Gammon ST, Kaye J, LeBleu VS, Mittendorf EA, Weitz J, Rahbari N, Reissfelder C, Pilarsky C, Fraga MF, Piwnica-Worms D, Kalluri R (2015) Glypican-1 identifies cancer exosomes and detects early pancreatic cancer. Nature 523:177-182. 
174. Manek R, Moghieb A, Yang Z, Kumar D, Kobessiy F, Sarkis GA, Raghavan V, Wang KKW (2018) Protein biomarkers and neuroproteomics characterization of microvesicles/exosomes from human cerebrospinal fluid following traumatic brain injury. Mol Neurobiol 55:6112-6128.

175. Verderio C, Muzio L, Turola E, Bergami A, Novellino L, Ruffini F, Riganti L, Corradini I, Francolini M, Garzetti L, Maiorino C, Servida F, Vercelli A, Rocca M, Dalla Libera D, Martinelli V, Comi G, Martino G, Matteoli M, Furlan R (2012) Myeloid microvesicles are a marker and therapeutic target for neuroinflammation. Ann Neurol 72:610-624.

176. Alvarez-Erviti L, Seow Y, Yin H, Betts C, Lakhal S, Wood MJ (2011) Delivery of siRNA to the mouse brain by systemic injection of targeted exosomes. Nat Biotechnol 29:341-345.

177. Ha D, Yang N, Nadithe V (2016) Exosomes as therapeutic drug carriers and delivery vehicles across biological membranes: current perspectives and future challenges. Acta Pharm Sin B 6:287-296.

178. Zhou X, Xie F, Wang L, Zhang L, Zhang S, Fang M, Zhou F (2020) The function and clinical application of extracellular vesicles in innate immune regulation. Cell Mol Immunol 17:323-334.

179. Saint-Pol J, Gosselet F, Duban-Deweer S, Pottiez G, Karamanos Y (2020) Targeting and crossing the blood-brain barrier with extracellular vesicles. Cells 9:851.

180. Yáñez-Mó M, Siljander PR, Andreu Z, Zavec AB, Borràs FE, Buzas EI, Buzas K, Casal E, Cappello F, Carvalho J, Colás E, Cordeiro-da Silva A, Fais S, Falcon-Perez JM, Ghobrial IM, Giebel B, Gimona M, Graner M, Gursel I, Gursel M, Heegaard NH, Hendrix A, Kierulf P, Kokubun K, Kosanovic M, KraljIglic V, Krämer-Albers EM, Laitinen S, Lässer C, Lener T, Ligeti E, Linē A, Lipps G, Llorente A, Lötvall J, Manček-Keber M, Marcilla A, Mittelbrunn M, Nazarenko I, Nolte-'t Hoen EN, Nyman TA, O’Driscoll L, Olivan M, Oliveira C, Pállinger É, Del Portillo HA, Reventós J, Rigau M, Rohde E, Sammar M, Sánchez-Madrid F, Santarém N, Schallmoser K, Ostenfeld MS, Stoorvogel W, Stukelj R, Van der Grein SG, Vasconcelos MH, Wauben MH, De Wever O (2015) Biological properties of extracellular vesicles and their physiological functions. J Extracell Vesicles 4:27066.

181. Wood MJ, O'Loughlin AJ, Samira L (2011) Exosomes and the blood-brain barrier: implications for neurological diseases. Ther Deliv 2:1095-1099.

182. Rajendran L, Honsho M, Zahn TR, Keller P, Geiger KD, Verkade P, Simons K (2006) Alzheimer's disease beta-amyloid peptides are released in association with exosomes. Proc Natl Acad Sci U S A 103:11172-11177.

183. Eitan E, Hutchison ER, Marosi K, Comotto J, Mustapic M, Nigam SM, Suire C, Maharana C, Jicha GA, Liu D, Machairaki V, Witwer KW, Kapogiannis D, Mattson MP (2016) Extracellular vesicle-associated $\mathrm{A} \beta$ mediates trans-neuronal bioenergetic and $\mathrm{Ca}^{2+}$-handling deficits in Alzheimer's disease models. NPJ Aging Mech Dis 2:16019.

184. Lim CZJ, Zhang Y, Chen Y, Zhao H, Stephenson MC, Ho NRY, Chen Y, Chung J, Reilhac A, Loh TP, Chen CLH, Shao H (2019) Subtyping of circulating exosome-bound amyloid $\beta$ reflects brain plaque deposition. Nat Commun 10:1144.

185. Stuendl A, Kunadt M, Kruse N, Bartels C, Moebius W, Danzer KM, Mollenhauer B, Schneider A (2016) Induction of a-synuclein aggregate formation by CSF exosomes from patients with Parkinson's disease and dementia with Lewy bodies. Brain 139(Pt 2):481-494.

186. Gustafsson G, Lööv C, Persson E, Lázaro DF, Takeda S, Bergström J, Erlandsson A, Sehlin D, Balaj L, György B, Hallbeck M, Outeiro TF, Breakefield XO, Hyman BT, Ingelsson M (2018) Secretion and uptake of $\alpha$-synuclein via extracellular vesicles in cultured cells. Cell Mol Neurobiol 38:1539-1550.

187. Jeon I, Cicchetti F, Cisbani G, Lee S, Li E, Bae J, Lee N, Li L, Im W, Kim M, Kim HS, Oh SH, Kim TA, Ko JJ, Aubé B, Oueslati A, Kim YJ, Song J (2016) Human-to-mouse prion-like propagation of mutant huntingtin protein. Acta Neuropathol 132:577-592.

188. Gorabi AM, Kiaie N, Barreto GE, Read MI, Tafti HA, Sahebkar A (2019) The therapeutic potential of Mesenchymal stem cell-derived exosomes in treatment of neurodegenerative diseases. Mol Neurobiol 56:8157-8167. 